\title{
ANALISIS PERSEPSI MASYARAKAT UMUM TERHADAP PRODUK INVESTASI SYARIAH DAN KEPUTUSAN UNTUK BERINVESTASI
}

\author{
Emilia Septiani ${ }^{1}$, Budi Santoso ${ }^{2}$, Mulyadi $^{3}$, Muhdin $^{4}$ \\ ${ }^{1}$ Fakultas Ekonomi dan Bisnis Universitas Mataram, emiliaseptiani@unram.ac.id \\ ${ }^{2}$ Fakultas Ekonomi dan Bisnis Universitas Mataram, hebato@yahoo.com \\ ${ }^{3}$ Fakultas Ekonomi dan Bisnis Universitas Mataram, mulyadiunram@gmail.com \\ ${ }^{4}$ Fakultas Ekonomi dan Bisnis Universitas Mataram,
}

\begin{abstract}
ABSTRAK
Tujuan dari penelitian ini adalah untuk mengetahui persepsi masyarakat umum Kota Mataram dalam hal produk dan lembaga keuangan yang menyediakan produk investasi syariah serta keputusan masyarakat dalam berinvestasi produk syariah. Metode pengumpulan data yang digunakan dalam penelitian ini adalah sample survey. Teknik pengambilan sampel dalam penelitian ini menggunakan purposive sampling dengan jumlah sampel sebanyak 100 orang. Alat analisis yang digunakan dalam penelitian ini adalah indeks persepsi masyarakat dan pengambilan keputusan berdasarkan jawaban "Ya" atau "Tidak" dari responden.

Hasil penelitian ini menunjukkan bahwa persepsi masyarakat umum Kota Mataram terhadap produk investasi syariah adalah baik. Namun masyarakat masih memiliki keragu-raguan terhadap prinsip syariah yang digunakan oleh lembaga keuangan syariah, baik lembaga keuangan bank maupun bukan bank. Dari 100 orang responden penelitian, 58 orang memutuskan untuk berinvestasi produk syariah.
\end{abstract}

Kata Kunci: Persepsi masyarakat, produk investasi syariah, keputusan berinvestasi

\section{ABSTRACT}

The purpose of this study were to determine the general public perception of Mataram City in terms of products and financial institutions that provide sharia investment products and decisions society to invest in sharia products. Data collection method used in this research is sample survey. Sampling technique in this research use purposive sampling with amount of sample counted 100 people. The analytical tools used in this research are the public perception index and decision-making was based on 'Yes' or 'No' answeared from the respondents.

The result of this study showed that the perception of the general public in the city of Mataram toward sharia investment products is good. In spite of the people are still have doubt about the sharia principles used by Islamic financial institutions, both bank financial institutions or non-bank financial institutions. For investment decisions, from 100 respondent, 58 people decided to invest sharia products.

Keywords: Public Perception, Sharia Investment Products, Investment Decisions.

\section{PENDAHULUAN}

Konsep keuangan syariah saat ini telah berkembang dengan sangat baik. Negaranegara Timur Tengah dan Asia Tenggara dapat dikatakan sebagai pelopor dari berkembangnya produk-produk keuangan syariah. Selain negara-negara tersebut, produk keuangan dan investasi syariah juga telah diterima di beberapa negara Asia, 
Eropa, Australia bahkan Amerika Serikat yang mayoritas penduduknya beragama bukan Islam.

Di Indonesia sendiri pada dasarnya prinsip keuangan syariah ini telah mulai dirintis pada tahun 1911 dengan didirakannya organisasi Serikat Dagang Islam yang dipelopori oleh para pengusaha dan para tokoh Islam pada saat itu (Agustianto, 2011). Namun sayangnya beberapa tahun setelahnya, perkembangan ekonomi Islam di Indonesia seolah kehilangan momentumnya. Barulah pada tahun 1992 (legitimasi menurut UU No.7 Tentang Perbankan) dengan didirikannya Bank Muamalat Indonesia (BMI) geliat keuangan syariah di Indonesia mulai menunjukkan perkembangan yang sangat positif (Agustianto, 2011). Setelah didirikannya BMI, berikutnya didirikan Asuransi Syariah Takaful pada tahun 1994 yang diikuti dengan berdirinya 78 Bank Perkreditan Rakyat (BPR) syariah (Agustianto, 2001).

Dengan berdirinya BMI dan BPR syariah, geliat investasi syariah semakin terasa di Indonesia. Banyak lembaga-lembaga keuangan konvensional membentuk lini syariah akibat dari krisis keuangan global yang mengakibatkan beberapa lembaga keuangan konvensional berskala besar mengalami kebangkrutan dan justru lembaga keuangan dengan prinsip syariah mampu bertahan dari krisis keuangan tersebut. Selain itu, menurut Antonio (2001), terdapat 63 bank telah ditutup, 14 bank di take over, dan 9 bank harus direkapitulasi dengan biaya ratusan triliun rupiah dari uang negara khusus di Indonesia dan Asia akibat dari terjadinya krisis ekonomi yang mengindikasikan adanya ketidaksesuaian sistem perbankan. Khan dan Mirakhor (1989) juga menyatakan bahwa lembaga keuangan Islam (syariah) akan lebih stabil di dalam menghadapi gejolak perekonomian eksternal jika dibandingkan dengan lembaga keuangan konvensional.

Lembaga-lembaga keuangan syariah menyediakan beragam bentuk investasi syariah. Investasi syariah merupakan jenis investasi yang menggunakan prinsip yang berbeda dengan investasi konvensional, baik dari segi proses maupun sifatnya. Investasi syariah tidak mengandung bunga atau riba di dalam keuntungan investasi tetapi menerapkan sistem bagi hasil atau nisbah sehingga tidak ada kewajiban yang dimiliki oleh lembaga investasi kepada investor syariah (Dixon, 1992). Dengan kata lain, segala bentuk keuntungan atau bahkan kerugian ditanggung bersama oleh pihak-pihak yang terlibat dalam kegiatan investasi tersebut.

Investasi syariah yang disediakan oleh lembaga keuangan syariah cenderung beragam. Mulai dari investasi yang memiliki risiko kecil (cenderung bebas risiko) seperti tabungan syariah dan/atau deposito syariah sampai investasi syariah yang memiliki risiko sedang dan/atau tinggi seperti asuransi syariah, saham syariah, dan reksadana syariah. Investasi syariah ini dapat dilakukan sesuai dengan jumlah dana yang dimiliki. Misalkan untuk investasi dalam bentuk deposito syariah, BMI dan Bank Syariah Mandiri menentukan setoran deposito minimal sebesar 10.000.000 rupiah. Untuk reksadana, dana yang diperoleh dari masyarakat dikelola oleh manajer investasi sayariah yang akan menyalurrkannya kepada emiten yang masuk dalam indeks saham syariah seperti emiten yang terdaftar dalam Jakarta Islamic Index (JII). Emiten yang terindeks syariah ini merupakan emiten yang bergerak dalam suatu bidang usaha yang memperoleh keuntungan secara halal, tidak riba, dan emiten yang bersangkutan dikenakan kewajiban untuk membayar zakat. Tambahan pula, seluruh saham yang berbasis syariah tersebut mendapatkan pengawasn langsung secara ketat dari Dewan Pengawas Syariah Majelis Ulama Indonesia.

Perkembangan lembaga keuangan yang menyediakan berbagai jenis investasi syariah saat ini tidak serta-merta menjadikan masyarakat memiliki persepsi yang baik 
terhadap investasi berbasis syariah tersebut sehingga sebagian besar masyarakat masih mengalami keragu-raguan untuk berinvestasi syariah. Hal ini dikarenakan sebagian besar masyarakat menganggap bahwa investasi bagi hasil ini memiliki risiko yang cukup besar dibandindingkan dengan investasi non-bagi hasil (Andraeny, 2011).

Hasil riset dari Islamic Research and Training Institute (IRTI) tahun 2016 menunjukkan bahwa perkembangan keuangan syariah di Indonesia dapat dikatakan lambat jika dibandingkan dengan negara tetangga. Hal ini terlihat dari share bank syariah yang masih berada pada kisaran 4,8 persen dari total industri perbankan, reksadana syariah juga masih $4,5 \%$, sukuk sebagai salah satu alernatif investasi juga masih 3,2 persen. Untuk Industri Keuangan Non-Bank (IKNB) hanya berkontribusi 3,1 persen Selain itu, peluang investasi sektor ritel juga masih dikuasai oleh dua bank besar, yaitu Bank Muamalat dan Bank Syariah Mandiri (BSM) (Handoko, 2017). Nusa Tenggara Barat (NTB) yang merupakan salah satu provinsi di Indonesia yang mayoritas masyarakatnya beragama Islam, memiliki kontribusi yang dapat dikatakan sangat kecil meskipun terlihat adanya perkembangan namun masih belum signifikan. Sebagai daerah dengan masyarakat yang religius, Kota Mataram pada khususnya dan NTB pada umumnya memiliki potensi yang sangat besar untuk mengembangakan pasar produkproduk investasi syariah. Market share dari lembaga keungan syariah di NTB masih di angka $8 \%$ per tahun 2015. Oleh karena itu, penelitian ini dilakukan untuk melihat persepsi masyarakat umum mengenai investasi syariah dan keputusan untuk berinvestasi.

\section{Identifikasi Permasalahan}

Perkembangan produk investasi syariah di NTB memang bernilai positif, tetapi tidak signifikan. Padahal masyoritas penduduknya beragama Islam, dimana dalam ajaran Agama Islam sangat dianjurkan untuk menggunakan prinsip syariah diberbagai aspek kehidupan, tidak terkecuali dalam berinvestasi.

\section{Tujuan Penelitian}

Berdasarkan uraian pada latar belakan dan identifikasi masalah, maka tujuan dari dilakukannya penelitian ini adalah sebagai berikut:

1. Untuk mengetahui persepsi masyarakat terhadap investasi syariah dalam hal produk dan lembaga investasi.

2. Untuk mengetahui keputusan masyarakat dalam berinvestasi syariah.

\section{TINJAUAN LITERATUR}

\section{Persepsi}

Hampir segala sesuatu yang dirasakan oleh seseorang diakibatkan karena adanya rangsangan. Menurut Setiadi (2003:159): "Rangsangan (stimulus) adalah sebuah unit input yang merangsang satu atau lebih dari lima panca indera, baik itu penglihatan, penciuman, rasa, sentuhan, dan pendengaran". Namun sayangnya tidak semua orang dapat menerima rangsangan yang diberikan oleh lingkungan sekitar mereka dengan baik. Untuk itu terdapat sebuah keterbukaan yang selektif (selective exposure) untuk menentukan rangsangan mana yang harus mereka perhatikan atau harus diabaikan. Disinilah peran dari persepsi. Menurut Stanton (2003), persepsi dartikan sebagai suatu makna yang dapat diperhatikan berdasarkan pengalaman dari masa lalu seseorang dan 
adanya stimuli atau rangsangan-rangsangan yang diterima melalui kelima indera yang dimiliki oleh manusia pada umumnya. Setiadi (2003) mendefinisikan persepsi sebagai suatu proses bagaimana stimuli-stimuli yang diberikan diseleksi kemudian diorganisasikan dan pada akhirnya dapat diinterpretasikan.

Adapun persepsi seseorang tersebut dipengaruhi oleh beberapa hal sebagai berikut (Setiadi, 2003):

1. Karaktersitik dari stimuli, seperti warna, bau, dan rasa yang tergolong dalam stimulus sensory serta ukuran, posisi, dan kontras yang tergolong dalam faktor struktural.

2. Hubungan stimuli dengan sekelilingnya.

3. Kondisi yang ada dalam diri individu sendiri.

Adapun proses dari persepsi itu sendiri adalah sebagai berikut (Setiadi, 2003):

1. Seleksi Perseptual: terjadi ketika seorang konsumen menangkap dan kemudian melakukan pemilihan pada phsycological set (informasi yang ada pada memori konsumen yang bersangkutan) yang dimilikinya. Sebelum diseleksi, sebuah stimulus haruslah mendapat perhatian dan persepsi selektif terlebih dahulu. Perhatian dari seorang konsumen ini dapat terjadi secara sengaja ataupun tidak sengaja. Sedangkan untuk persepsi selektif terjadi pada saat seorang konsumen memiliki keterlibatan yang tinggi terhadap suatu merek produk sehingga ia berupaya untuk mengumpulkan informasi akan suatu produk tersebut dari berbagai sumber.

2. Organisasi Persepsi: hal ini berarti seorang konsumen mengelompokkan informasi dari berbagai sumber ke dalam sebuah pengertian yang lebih menyeluruh agar dapat dipahami maknanya dengan baik sehingga memudahkannya untuk bertindak. Prinsip penting dalam integrasi persepsi ini adalah penutupan (closure), pengelompokan (grouping) yang didalamnya terdapat tiga prinsip penting berupa kedekatan, kesaman dan kesinambungan, serta konteks (context) di mana stimuli yang diterima oleh konsumen akan cenderung dihubungkan dengan konteks kehidupan atau situasi yang melingkupi konsumen tersebut.

3. Interpretasi Perseptual: di sini individu memberikan interpretasi atas stimuli yang telah diterimanya. Bagian ini merupakan yang cukup sensitif, karena stimuli yang sama dapat saja diartikan berbeda oleh setiap individu.

Beberapa penelitian mengenai persepsi masyarakat terhadap lembaga keauangan syaariah sudah banyak dilakukan. Hasil penelitian Ariani (2007) dan Dini (2007) menunjukkan persepsi masyarakat umum ataupun nasabah bank syariah yang positif. Namun, penelitian yang dilakukan oleh Mukarom (2009) menunjukkan bahwa sebanyak 100 orang petani yang dijadikan responden penelitian tidak pernah melakukan akses (khususnya pembiayaan) ke lembaga keuangan syariah. Maka dari itu, penelitian ini mencoba untuk melihati persepsi masyarakat umum terhadap produk-produk investasi syariah yang ditawarkan oleh lembaga keaungan, baik bank maupun non-bank.

\section{Produk Investasi Syariah}

Saat ini produk-produk investasi syariah menjadi semakin beragam. Mulai dari produk investasi dengan risiko kecil sampai yang berisiko tinggi. Nasabah yang berinvestasi pada produk keuangan syariah tidak akan mendapatkan keuntungan berupa bunga, melainkan persentase bagi hasi (nisbah) atas keuntungan yang diperoleh dari pengelolaan uang nasabah (bagi lembaga keuangan bank). Meskipun dengan sistem bagi hasil dan nisbah disepakati sejak aawal, baik nasabah dan pihak bank tidak dapat 
mengetahui hasil atau keuntungan yang diperoleh secara pasti yang akan diterima oleh kedua belah pihak sebelum keuntungan hasil usaha tersebut diketahui pada akhir periode. Jika lembaga keuangan tersebut mengalami kerugian, maka nasabah juga akan menanggung kerugian tersebut. Berikut ini diuraikan mengenai beberapa produk investasi syariah yang ada di Indonesia, baik yang disediakan oleh lembaga keuangan bank maupun non-bank syariah.

1. Tabungan dan deposito Mudharabah. Mudharabah merupaka akad (perjanjian) antara nasabah sebagai pemilik modal dengan bank sebagai pengelola modal untuk memperoleh keuntungan. Keuntungan yang diperoleh bank sebagai pengelola modal nasabah akan dibagikan sesuai dengan nisbah yang telah disepakati bersama sejak awal dengan besaran yang tak tentu setiap periodenya dan disesuaikan dnegan hasil kinerja usaha dari bank yang bersangkutan. Oleh karena itu, tabungan dan desposito syariah ini masuk ke dalam kategori investasi, bukan saving seperti halnya di lembaga keuangan konvensional. Bagi nasabah tabungan dan deposito syariah dengan nilai di bawah Rp. 100 juta, dana nasabah tersebut dijamin oleh pemerintah sama halnya dengan lembaga keuangan bank konvensional.

2. Asuransi Syariah. Asuransi syariah memilik sedikit perbedaan dengan asuransi konvensional. Jika pada asuransi konvensional nasabah membeli perlindungan dari perusahaan asuransi dan premi yang dibayarkan akan menjadi milik perusahaan asuransi, pada asuransi syariah premi yang dibayar tetap menjadi milik nasabah. Dana yang terkumpul pun merupakan milik seluruh peserta asuransi, sehingga perusahaan asuransi hanya melakukan pengelolaan dana yang dititipkan oleh nasabag ke dalam investasi-investasi yang halal dan hasilnya dibagi sesuai dengan nisbah yang disepakati bersama. Selain itu, para nasabah juga mengikatkan diri untuk saling menolong jika ada nasabah lain yang mengalami musibah. Oleh karena itu, pada asuransi syariah terdapat pos yang disebut dengan rekening dana kebajikan yang dananya diambil dari premi para nasabah dan sejak awal sudah diikhlaskan untuk dihibahkan kepada peserta lain yang mendapat musibah.

3. Tabungan pendidikan. Beberapa bank syariah menyediakan produk tabungan pendidikan. Bank Syariah mandiri merupakan salah satu bank yang menyediakan Tabungan Investa Cendekia. Tabungan pendidikan ini tergolong dalam tabungan berjangka dengan setoran bulanan yang fleksibel dan memberikan hasil investasi yang lebih baik dari tabungan pendidikan konvensional. Jenis tabungan ini juga menyediakan asuransi (hasil dari kerja sama bank dengan perusahaan asuransi syariah) agar jika nasabah mengalami musibah, dana pendidikan anak tetap dapat terjamin.

4. Efek Syariah. Sejauh ini, investasi syariah di pasar modal selalu diidentikkan dengan Jakarta Islamic Index (JII) yang di dalamnya hanya terdiri dari 30 saham syariah yang tercatat di Bursa Efek Indonesia (BEI). Padahal terdapat efek syariah selain saham, yaitu Sukuk dan Reksadana Syariah. Sejak November 2007, Bappepam dan LK (sekarang OJK) telah mengeluarkan Daftar Efek Syariah (DES) yang berisikan daftar saham syariah yang ada di Indonesia. Dengan dikeluarkannya DES, diharapakan masayarakat akan lebih mudah untuk mengetahui saham-saham yang tergolong dalam saham sayriah. DES merupakan satu-satunya rujukan daftar saham syariah di Indoensia. Dengan adanya DES tersebut, BEI melakukan tindak lanjut berupa peluncuran Indeks Saham Syariah Indonesia (ISSI) pada tanggal 12 Mei 2011. Konstituen ISSI terdiri dari seluruh saham syariah yang tercatat di BEI. 
5. Sukuk Ritel. Sukuk ritel merupkana salah satu bentuk produk investasi syariah yang dikeluarkan oleh Pemerintah Indonesia dan di juala kepada Warga Negara Indonesia secara individu melalui agen penjual. Pembelian sukuk ritel ini dapat dikatakan terjangkau karena dapat dibeli mulai dari Rp. 5 juta sampai dengan Rp. 5 milyar. Sukuk ritel menjanjikan bagi hasil berupa pendapatan tetap setiap bulannya dan memungkinkan untuk mendapatkan capital gain jika dijual di pasara sekunder. Penerbitan produk invvestasi Sukuk Ritel ini didasarkan pada prinsip syariah dan telah mendapat Pernyataaan Kesesuaian Syariah (Opini Syariah) dari Dewan Syariah Nasional majelis Ulama Indonesia Nomor B-101/DSN-MUI/II/2017 pada tanggal 14 Februari 2017. Sukuk Ritel ini merupakan salah satu jenis surat berharga syariah yang mencerminkan bukti kepemilikan investor atas aset SBSN yang disewakan. Akad yang digunakan adalah akad Ijarah.

6. Reksadana Syariah. Mekanisme investasi reksadana syariah ini mirip dengan reksadana konvensional. Antar sesama investor akan 'patungan' untuk berinvestasi ke dalam suatu produk keuangan yang pengelolaannya dilakukan oleh manajer investasi. Keuntungan yang diperoleh dari kegiatan investasi tersebut akan dibagikan kepada para investor sesuai dengan proporsi dana atau modal yang dimiliki dengan sedikit management fee untuk manajer investasi. Bedanya pada reksadana syariah, investasi yang dilakukan oleh manajer investasi, selain mempertimbangkan keuntungan juga perlu memperhatikan kehalalan dari produk investasi tersebut. Dengan begitu, hasil dari investasi yang dibagikan kepada para investor bersih dari riba dan unsur lainnya yang tidak halal. Jenis reksadana syariah yang ada saat ini adalah reksadana pendapatan tetap dan reksadana campuran, yang telah dierbitkan oleh bebrapa perusahaan sekuritas. Bank syariah biasanaya bertindak sebagai agen penjual. Tingkat pengembalian investasi reksadana syariah bervariasi antara 11-13\% per tahun .selain return yang bagus dan dirasa lebih adil, reksadana syariah memiliki harga yang cenderung lebih stabil.

\section{Keputusan Konsumen}

Sebelum memulai kegiatan pemasaran, sebuah perusahaan perlu mengidentifikasi apa yang menjadi kebutuhan dan keinginan calon konsumennya. Umumnya, keinginan konsumen untuk membeli suatu produk didasari pada keinginan atau ketertarikannya akan produk tersebut. Menurut Howard dan Shy (dalam Dharmmesta, 1998) proses pembelian melalui lima tahapan, yaitu:

1. Pemenuhan kebutuhan

2. Pemahaman kebutuhan

3. Proses mencari produk

4. Proses evaluasi

5. Keputusan pembelian

Kejelasan informasi dari suatu produk akan mendasari proses pembelian sehingga akan muncul kebutuhan. Jika kebutuhan akan suatu produk telah muncul, maka konsumen akan melakukan pertimbangan dan pemahaman terhadap kebutuhan tersebut. Apabila pemahaman konseumen atas kebutuhan tersebut sudah jelas, maka konsumen akan berusaha untuk mencari produk-produk untuk memuaskan atau memenuhi kebutuhannya tersebut. Keragaman pilihan produk pemuas kebutuhan akan menuntut konsumen untuk melakukan evaluasi produk yang paling sesuai atau tepat untuk memenuhi kebutuhannya. Jika hasil evaluasi produk tersebut sesuai dengan kebutuhan (biasanya juga diikuti dengan kemampuan) konsumen, maka keputusan 
untuk membeli produk tersebut dapat dilakukan. Namun apabila berdasarkan hasil evaluasi produk tidak sesuai dengan kebutuhan dan kemampuan pembeli dan/atau konsumen, maka keputusan untuk tidak membeli atau menunda pembelian dapat dilakukan.

Menurut Kotler dan Keller (2009), keputusan merupakan proses pendekatan penyelesaian masalah yang terdiri dari pengenalan masalah, pencarian informasi, penilaian alternatif, keputusan untuk membeli dan yang terkahir adalah perilaku pasca pemebelian. Handoko (2007) juga mengungkapkan bahwa keputusan pembelian merupakan sebuah proses pengidentifikasian semua pilihan yang mungkin untuk memecahkan masalah dan menilai pilihan-pilihan yang ada secara sistematis dan obyektif dan mempertimbangkan segala bentuk keuntungan dan kerugian dari masingmasing pilihan yang tersedia.

Keputusan merupakan salah satu elemen penting dari perilaku masyarakat dalam melakukan penilaian, memperoleh dan menggunakan suatu produk secara ekonomis. Persepektif pemecahan masalah akan mencakup semua jenis pemahaman kebutuhan dan faktor-faktor yang memotivasi serta mempengaruhi keputsan masyarakat untuk berinvestasi. Tedapat beberapa faktor yang mempengaruhi perilaku konsumen, yaitu (Kotler dan Keller, 2009):

1. Faktor Budaya. Kebudayaan merupakan suatu hal yang kompleks yang meliputi ilmu pengetahuan, kepercayaan, seni, moral, adat, kebiasaan, dan norma-norma yang berlaku pada masyarakat (Mangkunegara, 2005). Sub budaya dan kelas sosial menjadi hal yang penting di dalam perilaku pembelian. Budaya dapat dikatakn sebagai penentu keinginan dan perilaku masyarakat yang paling mendasar. Budaya dapat membentuk sub kelas sosial yang akan membedakan posisi seseorang dengan orang lainnya. Kelas sosial dapat didefinisikan sebagai suatu kelompok yang terdiri dari sejumlah orang yang memiliki kedudukan yang seimbang dalam kelas sosial yang berbeda dengan status sosial.

2. Faktor Sosial. Faktor sosial ini meliputi kelompok acuan, keluarga, peran dan status sosial. Kelompok acuan mengacu pada kelompok yang dapat mempengaruhi secara langsung maupun tak langsung terhadap sikap atau perilaku seseorang. Kelompok yang memiliki pengaruh secara langsung ini sering juga disebut sebagai kelompok keanggotaan, yang terdiri dari keluarga, teman, tetangga dan rekan kerja (kelompok primer) yang dapat saling berinteraksi secara terus-menerus secara informal. Kelompok acuan sekunder (kelompok keagamaan, profesi dan asosiasi) juga dapat mempengaruhi, hanya saja pengaruhnya tidak sebesar kelompok primer.

3. Faktor Pribadi. Selain faktor budaya dan sosial, karakteristik pribadi juga memiliki peran dalam mempengaruhi keputusan pembelian seseorang. Karakteristik pribadi ini meliputi usia, pekerjaan, keadaan ekonomi (pendapatan), kepribadian dan konsep diri, serta nilai dan gaya hidup seseorang. Karakteristik pribadi ini memiliki dampang langsung langsung pada perilaku konsumen.

4. Faktor Psikologis. Psikologis seseorang umumnya dipengaruhi oleh motivasi individu, persepsi, pembelajaran dan memori. Hal tersebut secara fundamental akan sangat mempengaruhi perilaku konsumen dalam menanggapi rangsangan yang diberikan oleh pemasar. 


\section{Kerangka Berpikir Penelitian}

Berdasarkan tujuan penelitian dan kajian teori, maka dapat digambarkan kerangka konsep penelitian sebagai berikut:

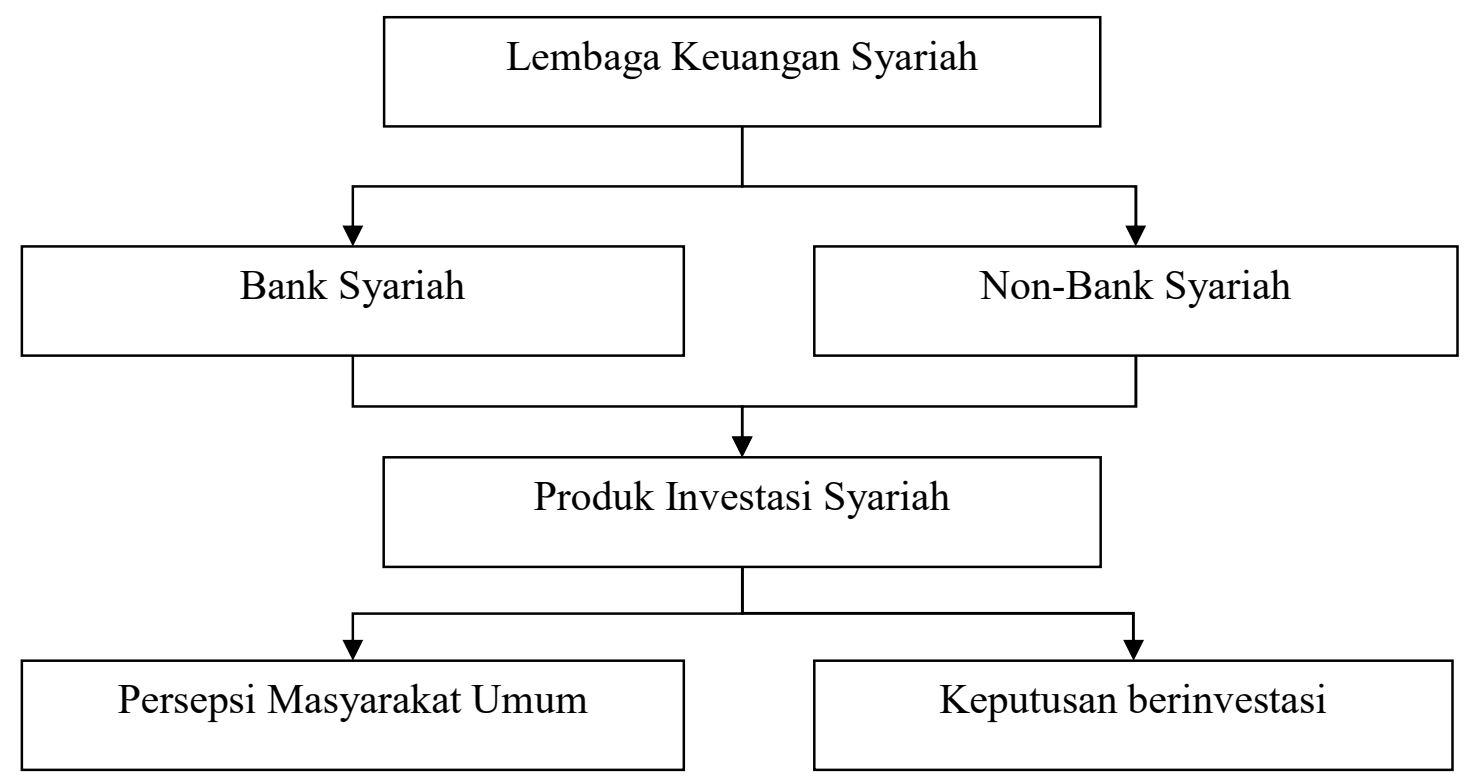

Gambar 3.1. Kerangka Berpikir Penelitian

Kerangka berpikir penelitian yang ada pada Gambar 1 menunjukkan arah penelitian yang akan dilakukan saat ini. Mengingat perkembangan lembaga keuangan syariah saat ini yang menyediakan berbagai macam produk investasi syariah cukup banyak dari segi jumlah namun pergerakannya lebih lambat dibandingkan dengan produk investasi konvensional lainnya, peneliti ingin melihat bagaimana persepsi masyarakat umum terhadap produk-produk investasi syariah yang ditawarkan oleh lembaga-lembaga keaungan syariah. Setelah mengetahui persepsi masyarakat umum tersebut, maka akan dilihat pula keputusannya untuk berinvestasi produk syariah.

\section{METODE PENELITIAN}

\section{Metode Pengumpulan Data}

Populasi dalam penelitian ini seluruh penduduk Kota Mataram. Jumlah penduduk Kota Mataram cukup besar dan tidak semua masyarakat mengetahui mengenai produk investasi syariah sehingga populasi sulit untuk diketahui dengan pasti. Maka dari itu, metode pengumpulan data yang digunakan untk penelitian ini adalah metode sample survey. Metode sample survey merupakan metode pengumpulan data yang dilakukan hanya terhadap sebagian dari anggota populasi (Sugiyono, 2007).

\section{Sampel Penelitian}

Jumlah sampel dalam penelitian ini adalah sebesar 100 orang responden. Jumlah ini didasari oleh pendapat Roscoe (1975, dalam Sekaran, 2006) yang menyatakan bahawa ukuran sampel lebih dari 30 dan kurang dari 500 adalah tepat untuk kebanyakan penelitian. Untuk memperoleh 100 orang responden ini digunakan teknik non- 
probability sampling dengan purposive sampling. Adapun kriteria dari penentuan responden ini adalah sebagai berikut:

1. Merupakan warga atau penduduk Kota Mataram.

2. Memiliki pekerjaan tetap, baik petani, wiraswasta, karyawan swasta maupun pegawai negeri (TNI/POLRI).

3. Memiliki penghasilan.

4. Mengetahui minimal salah satu produk investasi syariah (seperti: tabungan syariah, deposito syariah, tabungn pendidikan syariah, asuransi syariah, sukuk ritel, saham syariah dan reksadana syariah)

\section{Jenis dan Sumber Data}

Jenis data dalam penelitian ini yang kualitatif dan kuantitatif. Untuk data kualitatif ada beberapa data yang akan dikuantitaifkan (seperti: jawaban responden) agar memudahkan peneliti di dalam menginterpretasikan hasil. Sumber data dalam penelitian ini data primer berupa hasil jawaban responden yang diperoleh dari kuesionair yang dibagikan dan hasil wawancara. Sumber data sekunder juga digunakan dalam penelitian ini berupa data perkembangan produk syariah, jenis produk investasi yang disediakan oleh lembaga keungan syariah, dan informasi lain yang mendukung penelitian.

\section{Variabel Penelitian}

Adapun variabel pada penelitian ini adalah persepsi masyarakat yang ada di Kota Mataram Provinsi Nusa Tenggara Barat terhadap produk investasi syariah yang ditawarkan oleh lembaga keuangan syariah, baik itu lembaga keuangan bank maupun lembaga keuangan non-bank. Untuk melihat persepsi masyarakat ini akan digunakan skala pengukuran dengan menggunakan skala Likert dengan rincian sebagai berikut:

Tabel 1. Kriteria Pilihan Jawaban Responden

\begin{tabular}{|c|l|c|}
\hline No. & \multicolumn{1}{|c|}{ Pilihan Jawaban } & Skor \\
\hline 1 & Sangat Baik & 5 \\
\hline 2 & Baik & 4 \\
\hline 3 & Netral & 3 \\
\hline 4 & Tidak Baik & 2 \\
\hline 5 & Sangat Tidak Baik & 1 \\
\hline
\end{tabular}

Selain variabel persepsi, di dalam penelitian ini juga terdapat variabel keputusan berinvestasi. Keputusan berinvestasi merupakan keputusan masyarakat umum Kota Mataram Provinsi Nusa Tenggara untuk berinvestasi atau tidak berinvestasi produk syariah yang ditawarkan oleh lembaga keuangan syariah, baik itu lembaga keuangan bank maupun non-bank. Jadi, pilihan jawaban yang disediakan bagi responden hanya berupa 'Ya' dan 'Tidak' disertai dengan pertanyaan terbuka.

\section{Prosedur Analisis Data}

Penelitian ini dianalisis dengan dengan menggunakan statistik deskriptif (descriptive statistics) yang juga disebut statistik deduktif (deductive statistics). Statistik deskriptif merupakan analisis yang paling mendasar untuk menggambarkan keadaan data secara umum. Analisis statistik deskriptif ini dapat berupatabel frekuensi, eksplorasi data, tabulasi silang dan analisis rasio. Dalam penelitian ini data-data akan disajikan dalam bentuk tabel frekuensi dan 
tabel persepsi masyarakat umum. Tabel persepsi akan disusun berdasarkan indeks persepsi, seperti berikut:

Tabel 2. Indeks Persepsi Masyarakat

\begin{tabular}{|c|c|c|c|c|c|c|c|}
\hline \multirow{2}{*}{ No Resp. } & \multicolumn{6}{|c|}{ Aspek Persepsi } & \multirow{2}{*}{$\begin{array}{l}\text { Total } \\
\text { Skor }\end{array}$} \\
\hline & $\mathbf{A}$ & B & C & $\ldots$ & $\ldots$ & $\mathbf{Z}$ & \\
\hline \multicolumn{8}{|l|}{1} \\
\hline \multicolumn{8}{|l|}{2} \\
\hline …..... & & & & & & & \\
\hline \multicolumn{8}{|l|}{ Dst.... } \\
\hline $\mathrm{N}$ & & & & & & & \\
\hline \multicolumn{7}{|c|}{ Skor Keseluruhan } & $E$ \\
\hline
\end{tabular}

Sumber: Rusdan, dkk (2014)

Setelah indeks persepsi masyarakat umum terhadap produk investasi syariah diketahui, maka kriteria nilai persepsi tersebut dapat digolongkan sesuai tabel berikut.

Tabel 3. Kriteria Persepsi Masyarakat

\begin{tabular}{|c|c|c|}
\hline No. & Angka Indeks & Persepsi \\
\hline 1 & $1,00-1,80$ & Sangat Tidak Baik \\
\hline 2 & $1,81 \leq 2,60$ & Tidak Baik \\
\hline 3 & $2,61 \leq 3,40$ & Netral \\
\hline 4 & $3,41 \leq 4,20$ & Baik \\
\hline 5 & $4,21 \leq 5,00$ & Sangat Baik \\
\hline
\end{tabular}

\section{HASIL PENELITIAN DAN PEMBAHASAN}

Kota Mataram merupakan salah satu wilayah di Provinsi Nusa Tenggara Barat (NTB) dengan mayoritas penduduk beragama Islam. Masyarakat selalu mempertimbangkan kehalalan dari setiap aspek kehidupannya. Tidak terkecuali mengenai lembaga keuangan dan produk investasi yang diperdagangkan. Lembaga keuangan syariah saat ini berupaya untuk menciptakan produk-produk investasi yang beragam seperti halnya produk investasi yang disediakan oleh lembaga keuangan konvensional dengan menekankan pada proses yang disesuaikan dengan Syariat Islam. Keberagaman produk investasi syariah ini diharapkan dapat menarik minat masyarakat untuk menginvestasikan kelebihan dana yang dimilikinya tanpa masyarakat perlu merasa cemas terhadapa halal atau tidaknya manfaat yang diperoleh dari kegiatan investasi tersebut.

Di Kota Mataram sendiri sudah cukup banyak lembaga keuangan yang muncul dengan mengusung program syariah atas produk-produk yang ditawarkan. Industri keuangan syariah di Mataram pun mencatat perkembangan yang positif, meskipun belum signifikan. Seperti diketahui bahwa market share lembaga keuangan syariah, khususnya perbankan yang menyediakan cukup banyak pilihan produk investasi syariah bagi masyarakat, hanya mencapai 8\% di seluruh Provinsi NTB per tahun 2015. Dengan kata lain bahwa masyarakat di Provinsi NTB lebih melirik lembaga keuangan 64 | Analisis Persepsi Masyarakat Umum Terhadap Produk Investasi Syariah... 
konvensional. Kontribusi terbesar dalam aset keuangan syariah dimiliki oleh pasar modal syariah (sukuk korporasi, reksadana syariah, dan sukuk negara).

Berdasarkan hasil penilaian terhadap persepsi responden terlihat bahwa pada dasarnya masyarakat Kota Mataram yang bersifat religius cenderung mempersepsikan produk-produk investasi syariah yang dihasilkan oleh lembaga-lembaga keuangan syariah, baik yang berskala nasional maupun lokal. Masyarakat Kota Mataram mempersepsikan dengan baik terkait dengan keragaman produk investasi syariah yang ditawarkan, kehalalan dari produk investasi yang disediakan mulai dari proses awal hingga pembagian keuntungan, dan kejelasan akad serta proses bagi hasil yang bersifat terbuka. Namun, masih ada masyarakat yang mempersepsikan tidak baik terutama dalam hal ketersediaan dan kejelasan informasi mengenai produk syariah yang ditawarkan oleh lembaga-lembaga keuangan serta kepercayaannya terhadap lembaga keuangan yang menyediakan produk investasi berbasis syariah. Kedua hal tersebut merupakan hal yang sederhana namun kedepannya akan sangat berpengaruh terhadap persepsi masyarakat umum lainnya yang berujung pada kepercayaan. Masyarakat Kota Mataram masih merasa sanksi dengan ke-syariah-an produk investasi syariah. Persepsi seluruh masyarakat yang positif atau baik harus dapat dibentuk agar mereka dapat percaya dengan produk investasi syariah.

Persespsi masyarakat Kota Mataram yang menilai baik terhadap produk investasi syariah ini sesuai dengan keputusannya untuk berinvestasi produk syariah. Lebih dari 50\% masyarakat Kota Mataram yang menjadi responen penelitian memutuskan untuk berinvestasi produk keuangan syaraih. Berdasarkan informasi yang diperoleh langsung oleh peneliti, terdapat beberapa hal yang menjadi daya tarik produk investasi syariah sehingga masyarakat berani memutuskan untuk berinvestasi yaitu:

1. Secara agama, kegiatan investasi dengan prinsip syariah lebih disarankan karena terkait dengan halal dan haram manfaat yang diperoleh nantinya.

2. Produk investasi syariah dirasa lebih menguntngkan, aman dan terpercaya (sesuai ajaran Islam).

3. Nisbah (bagi hasil) dilakukan secara terbuka sehingga tidak ada pihak yang merasa dicurangi atau dengan kata lain merapkan prinsip winwin.

Hasil dari penelitian ini juga menunjukkan bahwa produk investasi yang paling banyak diminati oleh masyarakat Kota Mataram adalah produk tabungan, terutama tabungan pendidikan syariah. Tabungan pendidikan syariah ini dianggap paling bermanfaat dan tidak memberatkan oleh nasabah syariah. Nasabah hanya perlu melakukan setoran minimal Rp. 100.000 - Rp. 10.000.000 tiap bulannya dengan jangka waktu $1-20$ tahun. Tabungan pendidikan syariah yang disediakan oleh salah satu bank berstatus BUMN bahkan sudah memasukkan unsur asuransi didalamnya sehingga masyarakat merasa mendapatkan lebih dari satu manfaat dengan hanya membeli satu produk investasi. Dari hal tersebut juga terlihat bahwa masayarakt Kota Mataram telah concern terhadap pendidikan dengan mengupayakan pembiayaannya dipersiapkan dengan cara yang sesuai dengan ajaran Islam.

Namun demikian, jika melihat proporsi masyarakat Kota Mataram yang memperspsikan baik hingga sangat baik atas produk investasi syariah lebih besar jika dibandingkan dengan jumlah responden yang memutuskan untuk melakukan inestasi produk syariah dengan persentase masing-masing $70 \%$ dan $58 \%$. Hal ini menunjukkan bahwa tidak semua masyarakat yang mempersepsikan baik kemudian memutuskan untuk berinvestasi. Terdapat $42 \%$ masayarakat Kota Mataram yang memutuskan untuk 
tidak berinvestai produk syariah. Banyak faktor yang dijadikan alasan oleh masyarakat, alasan-alasan tersebut antara lain:

1. Masyarakat masih banyak yang belum paham dan mengetahui produk investasi syariah dengan dalih kurangnya sosialisasi atau informasi dari pihak-pihak terkait.

2. Masyarakat masih merasa ragu-ragu dengan sistem syariah dari produk investasi tersebut, bahkan ada yang menyimpulkan bahwa kegiatan investasi yang dilakukan oleh penyedia produk investasi syariah masih jauh dari Syariah Islam.

3. Masyarakat merasa lebih aman untuk berinvestasi (terutama deposito, asuransi dan tabungan pendidikan) di lembaga keuangan konvensional.

4. Masyarakat Kota Mataram masih banyak yang memilih berinvestasi dalam bentuk aset tetap (tanah, rumah, kendaraan, dan emas).

Selain dari keempat alasan tersebut, hal mendasar lainnya adalah terkait dengan keragu-raguan masyarakat terhadap lembaga keuangan yang menyediakan produk investasi syariah. Hal ini berlaku terutama untuk lembaga keuangan bank. Seperti diketahui bahwa hampir semua lembaga keuangan bank syariah pada awalnya bermula dari lembaga keuangan konvensional. Bahkan sejauh ini lembaga keuangan berupa bank konvensional tersebut masih beroperasi dengan hasil yang memuaskan berbagai pihak. Dengan adanya dualisme sistem perbakan ini, masyarakat merasa prinsip syariah yang diterapakan oleh lembaga keuangan bank masih tercampur-baur dengan yang konvensional sehingga masih jauh dari prinsip non-riba'.

Dengan melihat beberapa alasan masyarakat tersebut, pihak-pihak terkait seperti lembaga keuangan syariah dan/atau pemerintah perlu memberikan informasi sebanyakbanyaknya dan sejelas-jelasnya kepada masyarakat agar masyarakat menjadi lebih kaya informasi sehingga memudahkanya untuk pengambilan keputusan. Selain akses informasi, masyarakat juga perlu diberikan kemudahan akses lokasi sehingga lembagalembaga keuangan syariah bisa lebih dekat dengan masyarakat.

\section{KESIMPULAN}

Berdasarkan hasil penelitian yang telah dilakukan dapat disimpulkan bahwa persepsi masyarakat umum Kota Mataram adalah baik terhadap produk investasi syariah. Persepsi yang baik ini secara tak langsung dikarenakan masyarakat Kota Mataram yang religius sehingga mayarakat menyambut baik hadirnya lembaga-lembaga keuangan berbasis syariah yang menyediakan berbagai produk investasi syariah. Maysarakat merasa bahwa produk investasi syariah memiliki banyak ragam produk, jelas kehalalannya, manfaat yang diperoleh disesuaikan dengan akad yang dilakukan saat awal berinvestas dan sistem bagi hasil (nisbah) yang dilakukan secara terbuka.

Persepsi masyarakat umum Kota Mataram yang baik juga beriringan dengan keputusan masyarakat untuk berinvestasi produk syariah. Masyarakat Kota Mataram memutuskan untuk berinvestasi produk syariah dengan alasan lebih aman, pasti halal, terpercaya dan secara agama lebih disarankan. Namun demikian, cukup banyak pula masayarakat Kota Mataram yang masih belum tertarik dengan produk investasi syariah karena keterbatasan informasi dan pengetahuan mereka mengenai jenis produk dan proses syariah yang diberlakukan oleh penyedia produk. 


\section{REFERENSI}

Agustianto. (2001). Konsep dan Sistem Perbankan Syariah. Medan: FKEBI - SU.

Andreany, Dita. (2011). Analisis Pengaruh Dana Pihak Ketiga, Tingkat Bagi Hasil dan Non-Performing Financing Terhadap Bagi Hasil Pada Perbankan Syariah di Indonesia. Aceh: Simposium Nasional Akuntans XIV; Aceh, 21-22 Juli 20111.

Antonio, Muhammad Syafi'i. (2001). Bank Syariah Bagi Banker dan Praktisi Keuangan. Jakarta: Tazkia Institute. Gema Insani Press.

. (2001). Bank Syariah dari Teori Ke Praktek. Jakarta:

Ariani, Dian. (2007). Persepsi Masyarakat Umum Terhadap Bank Syariah di Medan. Tesis Sekolah Pascasarjana Universitas Sumatera Utara.

Bank Indonesia. (2002). Cetak Biru Pengembangan Perbankan Syariah di Indonesia. Jakarta: Bank Indonesia.

Bank Indonesia. (2007). Kebijakan Akselerasi Pengembangan Perbankan Syatriah Indonesia 2007-2008. Jakarta: Direktorat Perbankan Syariah.

Bank Indonesia. (2007). Kodifikasi Produk Perbankan Syariah. Jakarta: Bank Indonesia.

Bitta, Albert J. Della \& David L. Loudon. (1993). Consumer behaviour $\left(4^{\text {th }}\right)$. New Jersey: Prentice Hall.

Departemen Keuangan Republik Indonesia. (2009). Memorandum Informasi Sukuk Negara Ritel Seri SR 001. Jakarta: Deaprtemen Keuangan Republik Indonesia.

Dharmmesta, Basu Swastha. (1998). Theory of Planned Behaviour dalam Penelitian Sikap, Nilai dan Perilaku Konsumen, KELOLA; No. 18/VII/1998.

Dini, Aprilia Wahyu. (2007). Analisis Preferensi Nasabah Bank Syaria Di Kota Surakarta. Skripsi Fakultas Pertanian Universitas Sebelas Maret.

Dixon, Rob. (1992). Islamic Banking, The International Journal of Bank Marketing Vol.10 Iss.6; p.32-37.

Hamidi, M. Luthfi. (2003). Jejak-Jejak Ekonomi Syariah. Jakarta: Senayan Abadi Publishing.

Handoko, Luqman Hakim. (2017). Potret Industri Keuangan Syariah, Berita IAIN Surakarta. Rujukan: http://www.republika.co.id/berita/koran/opinikoran/16/03/28/o4qo3q12-potret-industri-keuangan-syariah

Handoko, T. Hani. (2012). Manajemen Edisi 2. Yogyakarta: BPFE Yogyakarta.

Howard, J.A and Shay, R.P. (1988). Measuring The Effect of Marketing Information on Buying Intention, The Journal of Service Marketing; Vol.2, Iss.4 Fall; p.27-36.

Kasmir. (2007). Bank Dan Lembaga Keuangan Lainnya Edisi Keenam. Jakarta: Rajawali Pers.

Khan, M and Mirakhor, A. (1989). The Financial System and Monetary Policy in an Islamic Economy, JKAU: Islamic Economics; 1 (1); p.39-57.

Kotler, Philip dan Kevin Lane Keller. (2009). Manajemen Pemasarn Edisi 12 Jilid I, Terjemahan: Benyamin Molan. Jakarta: P.T. Indeks.

Mangkunegara, Anwar Prabu. (2005). Sumber Daya Manusia Perusahaan. Bandung: Remaja Rosdakarya.

Mukarom, Ajen. (2009). Analisis Persepsi Petani Terhadap Lembaga Keuangan Syariah (Studi Kasus di Kecamatan Dramega Kabupaten Bogor). Skripsi Departemen Agribisnis Fakultas Ekonomi dan Manajemen Institut Pertanian Bogor. 
Rusdan, dkk. (2014). Persepsi dan Sikap Masyarakat Lingkar Gunung Rinjani Terhadap Industri Pariwisata (Suatu Upaya Menyongsong Rinjani sebagai Geopark Dunia), Laporan Penelitian. Magister Manajemen, Universitas Mataram. Sekaran, Uma. (2006). Metode Penelitian Untuk Bisnis. Jakarta: Salemba Empat.

Setiadi, Nugroho J. (2003). Perilaku Konsumen. Jakarta: Prenada Media. Stanton, William J. (2003). Prinsip Pemasaran Jilid I. Jakarta: Erlangga. Sugiyono. (2007). Metode Penelitian Bisnis. Bandung: Alfabeta.

68 | Analisis Persepsi Masyarakat Umum Terhadap Produk Investasi Syariah... 